\title{
INDIA
}

\section{WILD LIFE BOARD}

The first session of the Indian Board for Wild Life was held at Mysore from the 20th November to 1st December, 1952.

Chairman : Vice-Chairmen :
His Highness The Maharaja of Mysore.

Maharaj Dharmakumarsinhji of Bhavnagar. The Inspector-General of Forests.

Members :

Representatives of the Geological, Zoological, and Botanical Surveys of India, the National Institute of Sciences, the Ministries of Natural Resources and Scientific Research and of Transport, State Forest Departments, Zoological Gardens, Fisheries Development, and the Bombay Natural History Society. The Raja of Sandur, Mr. E. P. Gee, Mr. R. C. Morris, and Lieut.Col. R. W. Burton.

The Chairman demonstrating, in his inaugural address, the desperate need for nature conservation in India, without which there was no chance of the country's survival, said: "The unchecked exploitation of the resources of nature has resulted in the inevitable destruction of man-a fact verified in the rise and fall of civilizations, the world over. The inexorable revenge taken by nature on man is none the less sure and complete because it is slow and insidious in its operation. Floods and famines are nature's reply to the destructiveness of the axe and arrows of man. Cities which drew too heavily on the timber resources of neighbouring mountains have paid their penalty and lie silted over-a puzzle to archaeologists and a warning, if we can profit by it, to man.

"For the sake of present and transitory profits, man destroys irreparably. Lands once fertile are turned into deserts, and the deserts march ruthlessly onwards assisted by every wind that blows, establishing their barren sovereignty over land's once green valleys.

"The basis of all animal life is plant life. ... The link between plants and animals is more strong and intimate than is ordinarily imagined. . . . Over a definite area plants have established a sort of equilibrium ; certain kinds of plants, some large, others small, taking a permanent hold and living in ' a durable climax plant community' termed an Association. Different types and sizes of wild life communities establish themselves in a climax plant association thus formed. The mutual and long continued 
association of plant and animal communities establishes a balance and equilibrium which would be upset if the one or the other were disturbed by the uncontrolled ravages of man. The total extinction of certain forms of plant and animal life may be traced to the disturbance of this equilibrium by human agency. There is a growing body of intelligent opinion in India on the subject of game reserves; I wish to emphasize that all attempts at conservation of wild life will be futile unless they are considered in the context of the plant life with which wild life forms nature's harmony.

"As the results of the abuse of natural resources take a long time to reveal themselves, and as natural, recuperative forces are likewise slow in their operation, any plan and programme for the protection of nature and the conservation of natural resources will have necessarily to be based on a long range policy, kept well above the whims and accidents of party politics. It has to be handled on a national rather than a local footing, for the problems of nature protection belong to biographic and not to political units and divisions. Indeed the problem has an international bearing for the distribution of wild life has a geographical continuity crossing political boundaries. National parks, national reserves and national conservation measures have helped the protection of nature in the nation, but these have to be integrated into an international union and understanding. It is for these reasons that we have to bestir ourselves before it is too late to establish national parks and national reserves as a national trust, under statutory authority not subject to the casualties of party politics or departmental whims."

Later he made a particular appeal for the preservation of the Indian lion, surviving only in the Gir forests of Kathiwar.

"It is the lion's head that adorns the 'Asoka' pillar which is the motif of the Republic of India. India was closely connected with the lion in so many different ways. The lion has been the 'vahana' or vehicle of the 'Devi ', in her fight against forces of darkness and barbarism. The Devi is described as 'Mrigapathi skandhasthitham', 'one who has for her vehicle the lion' (or one who is seated on the back of the king of beasts). It is because of this association that the lion has become the symbol of 'Dharma' (Righteousness). In days of yore, the seat of the ruler, on which he sat to dispense justice was called 'Simhasana', the meaning being that it was the seat of the lion, upon which justice and fair-play rested."

The Board, in its resolutions, called attention to the need for 
national parks and reserves, which should be surrounded by buffer zones. It stated that measures were necessary to prohibit the indiscriminate use of guns allowed for crop protection, and for the inoculation against cattle diseases of all cattle grazing in the neighbourhood of reserves. It recommended that state wild life boards should be appointed and that publicity should be undertaken by the central and state publicity departments.

The following mammals and birds were especially recommended for protection :- Indian lion, snow leopard, clouded leopard, cheetah, rhinoceros (all species), Indian wild ass, Kashmir stag, musk deer, brow-antlered deer, pigmy hog, great Indian bustard, pink-headed duck, white-winged wood duck.

At the close of the meeting the Chairman expressed his belief that wide public interest had at last been aroused and that the deplorable ignorance and apathy of the past was disappearing. A splendid new chapter in the history of Indian public opinion was opening. 